\title{
Bylaws
}

\section{Draft of 2020 revisions}

\section{Article I. NAME AND AFFILIATION}

Section 1. Name

The name of the Organization shall be the Government Documents Round Table (GODORT) of the American Library Association (ALA).

Section 2. Relationship to the American Library Association

The Government Documents Round Table is a unit of the American Library Association. The constitution and bylaws of that organization, to the extent they are applicable, take precedence over the bylaws of this Round Table.

\section{Article II. PURPOSE}

The purposes of the Government Documents Round Table are: (a) to provide a forum for the discussion of problems and concerns and for the exchange of ideas by librarians working with government documents; (b) to provide a nexus for initiating and supporting programs to increase the availability, use and bibliographic control of documents; (c) to increase communication between documents librarians and the larger community of information professionals; (d) to contribute to the education and training of documents librarians.

\section{Article III. MEMBERSHIP}

Section 1.

Any member of ALA may elect to become a personal member of the Round Table upon payment of Round Table annual dues. Only Round Table members who are personal members of ALA receive the right to vote and hold office.

Section 2.
Any organization concerned with issues relating to government information shall be welcome to associate with the Round Table as an affiliate member upon submission of a statement of membership and purpose. Affiliate membership shall entitle the group to receive publications of the Round Table and to participate by reporting on activities for dissemination to the entire membership; it shall not entitle members of the group who are not personal members of ALA and members of the Round Table to vote or hold office in the Round Table. The functions and responsibilities of affiliates shall be defined in the GODORT Policies and Procedures Manual (PPM).

\section{Article IV. OFFICERS}

Section 1.

The executive officers of the Round Table are elected and shall be Chair, Assistant Chair/Chair-Elect, Immediate Past Chair, Secretary, Treasurer, GODORT Councilor, Publications Committee Chair, and Bylaws and Organization Coordinator. Terms of all elected officers shall be one year, unless otherwise specified in the Bylaws. Term of office shall begin at the start of new business at the Steering Committee meeting of the Annual Conference. The Treasurer shall take office September 1 and shall serve a two-year term. The Bylaws and Organization Coordinator shall serve a two-year term (with the option of a one-year term extension, at the discretion of the GODORT Chair and approval of the Steering Committee).
The GODORT Councilor's term of office is governed by the ALA Bylaws. Section 2.

All other officers of the task forees and standing committees and interest groups will shall be appointed. No member shall hold more than one office at a time at the level of standing committee Chair or Fask Force interest group Coordinator or higher. No member shall be eligible to serve more than two consecutive terms in the same office. No member of the Executive Committee, except for the past Chair, shall be eligible to hold an additional elective or appointive position with GODORT at the level of work group Chair or higher, except as specified in these Bylaws. This restriction shall not apply to appointment to special committees or task forces.

Section 3.

Chair, Assistant Chair/Chair-Elect, and Past Chair

a. The Chair shall have the customary duties of the office of Chair and shall preside over all meetings of the Government Documents Round Table and of the Executive Committee and the Steering Committee for fulfilling the purposes of this organization.

b. The Assistant Chair/Chair-Elect is responsible for program planning, shall serve as a member of the Nominating Committee, the Executive Committee, and the Steering Committee, and as Chair of the Program Committee.

c. The Immediate Past Chair shall serve as a member of the 
Section 4.

Executive Committee, the Steering Committee, and the Membership Committee and shall perform such duties as assigned by the GODORT Chair.

Secretary

The Secretary shall perform the customary duties of this office. The Secretary is a member of the Executive Committee and the Steering Committee. The Secretary shall keep an accurate record of all meetings of the Round Table and the Steering Committee and have these records available at or before the next regularly called meeting of the Round Table or Steering Committee; shall make a report of the proceedings of each annual meeting to ALA.

Section 5.

Treasurer

The Treasurer shall perform the customary duties of this office and serve on the Development Committee, the Publications Committee, the Executive Committee, and the Steering Committee.

Section 6.

Chair of the Publications Committee

The Chair shall, with the aid of the entire committee, perform the duties outlined in the PPM. The Chair of the Publications Committee is a member of the Steering Committee and the Executive Committee.

Section 7.

Councilor

The GODORT Councilor shall be elected in accordance with the ALA Bylaws and shall represent the interests of the Government Documents Round Table on the ALA Council. The GODORT Councilor is a member of the Steering Committee and the Executive Committee. The Councilor serves as an ex-officio member of the Legislation Committee. The Councilor reports to the Steering Committee and to the membership on ALA Council activities, and presents those ALA issues and Council documents upon which the Steering Committee may wish to act. The Councilor receives direction from the Steering Committee regarding ALA Council issues, and sponsors Council resolutions as requested by the Steering Committee.

Section 8.

Bylaws and Organization Coordinator

The Coordinator is responsible for maintenance of GODORT's Bylaws and timely updating of the Policies and Procedures Manual (to reflect current practice). It is not the responsibility of this Coordinator to initiate Bylaws amendments or to draft revisions to the PPM, but rather to receive these from GODORT membership, or appropriate GODORT units, and perform any necessary administrative and editorial tasks.

Section 9.

The following special officers shall serve the Chair and the Steering Committee:

a. An Archivist shall be appointed by the GODORT Chair and serve until either party terminates Archivist the term of office.

b. Website Administrator. The GODORT Website Administrator is responsible for developing and maintaining the GODORT website. The Website Administrator is an appointed position filled through an application and interview process and serves a three-year term of office, which is renewable.

c. Virtual Meetings Coordinator. The GODORT Virtual Meetings Coordinator provides support for GODORT virtual meetings by coordinating the usage of GODORT's virtual meeting space. The Virtual Meetings Coordinator is a non-voting member of the GODORT Steering Committee, appointed by the GODORT Chair. The Coordinator serves until either party terminates the term of office.

\section{Article V. MEETINGS AND QUORUM}

Meetings may be conducted in person, virtually, or a combination thereof.

Section 1.

All GODORT meetings will be open to anyone who wants to attend, unless otherwise indicated, but only GODORT members have voting privileges.

Section 2.

The meetings of the Government Documents Round Table are held as follows:

a. Membership meetings shall be held at ALA Midwinter Meetings and Annual Conferences.

b. The Steering Committee will meet at ALA Midwinter Meetings and Annual Conferences.

c. Fask Forces Interest Groups will meet at ALA Annual Conferences and as necessary.

d. The Nominating Committee will meet at least once prior to submitting a slate of candidates to ALA for inclusion in the ballot. 
e. Other committees will meet as necessary. Section 3.

The membership shall be given notice prior to all meetings. Section 4.

A quorum is constituted as follows:

a. Twenty-five members shall constitute a quorum at any GODORT membership meeting.

b. For committees and other bodies with designated specified membership, the presence of a majority of the members constitutes a quorum.

c. For task forces, work groups interest groups, discussion groups, and other bodies with unspecified membership, a quorum is the number of people attending the meeting.

Section 5.

The rules contained in the parliamentary authority designated by the American Library Association shall govern the Round Table in all cases in which they are applicable and in which they are not inconsistent with these Bylaws or any special rules of order the Round Table may adopt, or with the Constitution and Bylaws of the American Library Association.

\section{Article VI. STEERING COMMITTEE}

This committee is composed of the officers of the Round Table as defined in Article IV, task force coordinators, and the Chairs of standing committees and the Coordinators of interest groups.

Section 1.

The Steering Committee shall perform the following duties:

a. General supervision of the affairs of GODORT;

b. Approve the topic(s) of the program(s) for the Annual Conference;

c. Approve by majority vote the appointments and designations of Chairs/Coordinators made by the GODORT Chair to standing committees, interest groups and special committees ;

d. Approve creation, change, or discontinuation to membership of standing committees, task forces, interest groups, discussion groups, and special committees or task forces;

e. Approve official liaisons positions of GODORT, as needed and where positions may be filled;

f. Appoint members to ALA unit positions which accrue to the Chair ex officio; g. Solicit volunteers for recommendations to ALA committees;

h. Report all actions of the Steering Committee at Midwinter Meeting and Annual Conferences.

Section 2.

Vacancies on the Steering Committee and vacancies in other task foree offiees and committees caused by an incumbent's resignation, disability, etc. shall be filled for the remainder of the term by the Chair with the concurrence of a majority of the Steering Committee members.

Section 3.

Invitations to name a representative to serve as an ex-officio, non-voting member of the Steering Committee shall be extended by the Committee to organizations sharing common interest and purposes with GODORT.

Section 4.

Ex-officio memberships on the Steering Committee shall be reviewed periodically.

\section{Article VII. EXECUTIVE COMMITTEE}

This committee is composed of the Chair, the Assistant Chair/ Chair-Elect, Secretary, Treasurer, GODORT Councilor, Publications Committee Chair, the Immediate Past Chair, and the Bylaws and Organization Coordinator.

The Committee shall act for GODORT when time constraints prevent convening or canvassing the Steering Committee. It shall also assist the Treasurer in the preparation of the budget, ensure that the budget is based on complete and accurate information provided by all GODORT units, and conduct budget reviews as requested by the GODORT chair. No action taken by this committee shall conflict with action taken by the Steering Committee. All action taken will be reported to the Steering Committee.

\section{Article VIII. TASKFORCES, STANDING COMMITTEES, INTEREST GROUPS, DISCUSSION GROUPS, AND SPECIAL COMMITTESS}

Section 1. Task Forces

a. Fask forces are action-oriented groups related to levels of government which are ereated to perform the ongo= ing work of the Round Table. Task forees are created, ehanged, or discontinued by the Steering Committee. Fask Forees can be ereated by the Steering Committee, or by the submission of a proposal with twenty= five supporting signatures of personal members. The 
Steering Committee, upon the recommendation of the eoneerned body, may discontinue or change the status of a task force. Officers of task forces shall be Goordinator and Assistant Coordinator and shall be appointed as provided in these Bytaws. Membership in a task foree is not speciffect or limited. Any GODORT member may be a member of a task foree in which he or she has an interest. All GODORT members attending a task foree meeting may vote.

b. A statement of the purpose, goals, and strueture of a task foree shall be submitted to the Steering Com= mittee for approval and inclusion in the PPM. It shall be the responsibility of each task foree to revise these statements as neeessary and to submit the revised state= ment to the Steering Committee. The work groups and eommittees of a task force are also required to prepare a statement of membership, purpose, goals, strueture and duration of operation which shall be approved by the task foree and forwarded to the Steering Commit= tee for approval and inclusion in the PPM.

Section 1 Z. Standing Committees

a. Standing committees shall be created to perform the ongoing work of the Round Table. Standing committees are created, changed, or discontinued by the Steering Committee. Committees can be created by the Steering Committee, or by the submission of a proposal with twenty-five supporting signatures of personal members. The Steering Committee, upon the recommendation of the concerned body, may discontinue or change the status of a committee.

b. A statement of the functions and membership of a new standing committee shatl must be written into the PPM at the committee's creation. Membership changes shall be approved by the Steering Committee and the PPM updated. New committee chairs (with the exception of the position for Publications Committee Chair) shall be appointed by the GODORT Chair with the concurrence of a majority of the Steering Committee members. Committees can appoint subunits for specific tasks. No member of a standing committee shall be eligible to serve more than two consecutive terms on the same committee. Policies of standing committees shall be submitted to the Steering Committee for approval and inclusion in the PPM.
Section 2 5. Interest Groups

An interest group is an informal group welcoming all ALA members for participation in discussions. The Steering Committee must approve a statement of each interest group's purpose and duration for inclusion in the PPM. The interest group teader coordinator is appointed by the GODORT Chair with the concurrence of a majority of the Steering Committee members. The coordinator's role is to define discussion topics, coordinate discussion, and report back to GODORT membership as appropriate. No coordinator of an interest group shall be eligible to serve more than two consecutive terms on the same interest group.

Section 34 . Discussion Groups

A discussion group is an informal group that allows for the discussion of topics of common interest. The Steering Committee must approve a statement of each discussion group's purpose and duration for inclusion in the PPM. The discussion group leader is appointed approved by the GODORT Chair to define discussion topics, coordinate discussion and report back to GODORT membership as appropriate.

Section 4 3. Special Committees and Task Forces.

The Steering Committee may establish special committees or task forces for any particular or specific purpose within the purview of the Round Table. Special committees shall be of limited and specified duration. In creating a special committee, the Steering Committee must approve a statement of its purpose, organization, membership and duration. This statement will be included in the PPM. Upon completion of the task assigned to any special committee or task force, a report covering any conclusions, outcomes or recommendations shall be presented to the Steering Committee.

Section 56.

The Steering Committee will conduct a periodic review to ensure that all groups continue to serve their purpose.

\section{Article IX. POLICIES AND PROCEDURES}

Operating policies and procedures of GODORT and its subunits are contained in the GODORT Policies and Procedures Manual. The PPM will be maintained by the Bylaws and Organization Coordinator in consultation with other GODORT units, and is published on the GODORT website. 


\section{Article X. FINANCES}

Section 1.

Funds to support Round Table activities will come from the dues of the general membership, contributions, and monies from workshops and publications.

Section 2.

Dues for personal members, affiliate groups, and others shall be proposed by the Steering Committee and presented to the membership for approval or revision at its annual meeting.

Section 3.

The Steering Committee shall prepare a budget for the next fiscal year and present it to the membership at its meeting immediately prior to the ALA budget submission deadline.

Section 4.

The Steering Committee shall have control of all monies earned or expended by the Round Table. Officers, committee chairs and task force coordinators may request funds as necessary to implement approved programs of the organization.

Section 5.

The Treasurer is authorized to approve requests for reimbursement and payment of bills from funds in the custody of the ALA Executive Board.

\section{Article XI. AMENDMENTS}

Section 1.

These Bylaws may be amended by a majority vote of the members of the Round Table in attendance and voting at any Annual Conference or Midwinter Meeting, provided that notice of the proposed version has been sent to members or published in DttP at least thirty days prior to the meeting. These Bylaws may also be amended by a majority vote of those responding in a referendum to personal members, provided that notice of the proposed revision has been sent to members or published in $D t t P$ at least thirty days prior to the vote.

Section 2.

Proposals for revision may be sent by any member of the Steering Committee to the Bylaws and Organization Coordinator, who will review the proposed revision and report it to the Steering Committee. Upon approval by the Steering Committee, the proposed revision shall be disseminated to the membership as provided for in this article.

Section 3.

Any personal member(s) may propose amendments with twenty-five supporting signatures. In order to obtain the supporting signature a proposed amendment may be published on the GODORT website with an accompanying form which supporters may sign and return to the Bylaws and Organization Coordinator. Upon receipt of a proposal with twenty-five supporting signatures from personal members, the Bylaws Coordinator will review and report on the language and compatibility of the proposal with other provisions in these Bylaws to the GODORT membership. The proposed amendment will be republished on the GODORT website, and discussed and voted on as provided in this Article, Section 1. 